University of Nebraska - Lincoln

DigitalCommons@University of Nebraska - Lincoln

July 2004

\title{
CLARIFICATION ON THE NOMENCLATURAL STATUS OF SIX GENUS-GROUP NAMES IN THE TRIBE TRICHIINI (COLEOPTERA: SCARABAEIDAE: CETONIINAE)
}

Andrew Smith

asmith@unl.edu

Follow this and additional works at: https://digitalcommons.unl.edu/entomologypapers

Part of the Entomology Commons

Smith, Andrew, "CLARIFICATION ON THE NOMENCLATURAL STATUS OF SIX GENUS-GROUP NAMES IN THE TRIBE TRICHIINI (COLEOPTERA: SCARABAEIDAE: CETONIINAE)" (2004). Papers in Entomology. 15. https://digitalcommons.unl.edu/entomologypapers/15

This Article is brought to you for free and open access by the Museum, University of Nebraska State at DigitalCommons@University of Nebraska - Lincoln. It has been accepted for inclusion in Papers in Entomology by an authorized administrator of DigitalCommons@University of Nebraska - Lincoln. 


\title{
Clarification on the Nomenclatural Status of Six Genus-Group Names in the Tribe TrichiIni (Coleoptera: Scarabaeidae: Cetonitnae)
}

\author{
ANDREw B. T. SMITH \\ Division of Entomology, W436 Nebraska Hall \\ University of Nebraska State Museum \\ Lincoln, NE 68588-0514, U.S.A.
}

\begin{abstract}
Six genus-group names in the tribe Trichiini (Coleoptera: Scarabaeidae: Cetoniinae) are discussed with regards to their availability and validity under the International Code of Zoological Nomenclature. Aleurostictus Kirby, Archimedius Kirby, Euclidius Kirby, Gymnodus Kirby, Tetrophthalmus Kirby, and Trichinus Kirby all have priority over most other generic names in the tribe but none of the names are in prevailing usage. Clarifications are needed due to the reemergence of Aleurostictus Kirby in current literature and confusion over the nomenclatural status of the other names. Type species are designated for Aleurostictus Kirby, Tetrophthalmus Kirby, and Stegopterus Burmeister and Schaum. The gender of the genera Trigonopeltastes Burmeister and Schaum and Apeltastes Howden is also discussed.
\end{abstract}

Within the tribe Trichiini, there has been some confusion and nomenclatural instability caused by the reemergence of several long-forgotten genus-group names erected by Kirby (1827). The purpose of this paper is to stabilize the nomenclature within this group by clarifying the status of each of these names. In order to do this, three of Kirby's generic names must undergo a reversal in precedence to be junior synonyms of younger names in order to preserve "prevailing usage." Article 23.9.2 of the International Code of Zoological Nomenclature (International Commission on Zoological Nomenclature 1999; hereafter called the Code) is used to reverse the precedence of Gymnodus Kirby with a younger name because it is not in prevailing usage. Archimedius Kirby and Euclidius Kirby both undergo a reversal in precedence with Trigonopeltastes Burmeister and Schaum using Article 23.12.1 and based on the actions of Howden (1968). An application has been accepted to the Bulletin of Zoological Nomenclature (Case 3314) to maintain the prevailing usage of the genus Trichiotinus by reversing the precedence with the unused older name Trichinus Kirby and to maintain the prevailing usage of the genus Stegopterus by reversing the precedence with the unused older name Tetrophthalmus Kirby. Finally, Dechambre (2001) previously reversed the precedence of Aleurostictus Kirby (with Gnormius LePeletier and Serville) using Article 23.9.2 of the Code.

In the time of Linnaeus, Olivier, and Fabricius (1758-1819), scarab beetles were divided up into only a handful of genera. For example, what is now recognized as the subfamily Cetoniinae contained only five genera (Cetonia Fabricius, Cremastocheilus Knoch, Goliathus Lamarck, Trichius Fabricius, and Valgus Scriba). From the 1820s on, taxonomists began major splitting of scarab beetle genera to accommodate the diversity and morphological variation within these groups. Kirby (1827) recognized that the genus Trichius contained vastly different species and attempted to divide the group into seven subgenera. For reasons unknown, Kirby's names quickly fell into disuse and have not been used as valid taxa in over 160 years.

When Kirby (1827) named these subgenera, he did it in Latin text as a plural noun. Therefore each of the names ended with " $i$ " instead of the standard "us" ending. This has caused confusion and several subsequent authors rejected Kirby's names on this 
basis. Kirby explicitly stated that the gender of all genera were to be male from his statement "Instead of giving the denominations of the subgenera a feminine termination as proposed in the Introduction to Entomology, I have followed the gender of the genus [Trichius].' ' In this case, Article 11.8.1 should be used to correct the endings of the six subgenera so the generic names are in the nominative singular while retaining the original author and date (justified emendations). The correct spelling, author, and date for these six generic names are given in bold headings below.

\section{Aleurostictus Kirby, 1827}

Aleurosticti: Kirby 1827 [original spelling].

Aleurostictus: Stephens 1839 [justified emendation].

Nomenclatural Status. Available but invalid name, junior synonym of Gnorimus LePeletier and Serville, 1828 as a reversal of precedence under Article 23.9.2 of the Code. This action was taken by Dechambre (2001) to counteract the erroneous resurrection of Aleurostictus as a valid name by Ádám (1994) and Tauzin (2000). Dechambre (2001) outlined the case against using Aleurostictus by pointing out that Tauzin (2000) violated Article 23.11 of the Code, which states that "If an author wishes to replace a name in prevailing usage by its older synonym when the conditions of Article 23.9.1 are met, he or she must apply to the Commission for a ruling under the plenary power.' No such application to the commission has been published in the Bulletin of Zoological Nomenclature. Additionally, the use of Aleurostictus as a valid name by Ádám (1994) and Tauzin (2000) (and subsequent authors such as Whitehead [2003]) all violate Article 23.9.6 which states "The deliberate use of a name contrary to Article 23.9.1, or the mentioning of a name in a synonymy, or its mere listing in an abstracting publication, or in a nomenclator or other index or list of names must not be taken into account in determining usage under Articles 23.9.1.1 and 23.9.1.2.' Tauzin (2000), Whitehead (2003), and perhaps others used Aleurostictus incorrectly because of the "deliberate use of a name contrary to Article 23.9.1." The use of Aleurostictus by Ádám (1994) is not to be considered for prevailing usage because it is listed in a checklist, which is a "mere listing in an... index or list of names." The nomenclatural action of Dechambre (2001) permanently gives Gnorimus priority over Aleurostictus thus ending the debate over which name is valid.

Type Species. Scarabaeus nobilis Linnaeus, 1758 (now Gnorimus nobilis), here designated. Tauzin (2000) erroneously listed Scarabaeus nobilis as the type species "according to the original description." However, two species were explicitly listed in the genus with the original description so one is selected here as the type species.

\section{Archimedius Kirby, 1827}

Archimedii: Kirby 1827 [original spelling].

Archimedius: justified emendation.

Nomenclatural Status. Available but invalid name, junior synonym of Trigonopeltastes Burmeister and Schaum, 1840 as a reversal of precedence under Article 23.12. Howden (1968) recognized Archimedius as a synonym of Trigonopeltastes and explicitly declared the older name as a nomen oblitum. This action satisfies Article 23.12 in the Code permanently giving Trigonopeltastes precedence over Archimedius.

Type Species. Scarabaeus delta Forster, 1771 (now Trigonopeltastes delta) by monotypy.

\section{Euclidius Kirby, 1827}

Euclidii: Kirby 1827 [original spelling].

Euclidius: justified emendation. 
Nomenclatural Status. Available but invalid name, junior synonym of Trigonopeltastes Burmeister and Schaum, 1840 as a reversal of precedence under Article 23.12. Howden (1968) recognized Euclidius as a synonym of Trigonopeltastes and explicitly declared the older name as a nomen oblitum. This action satisfies Article 23.12 in the Code permanently giving Trigonopeltastes precedence over Euclidius.

Type Species. Trichius triangulus Kirby, 1819 (now Trigonopeltastes triangulus) by monotypy.

\section{Gymnodus Kirby, 1827}

Gymnodi: Kirby 1827 [original spelling].

Gymnodus: Kirby 1837 [justified emendation].

Nomenclatural Status. Available but invalid name, junior synonym of Osmoderma LePeletier and Serville, 1828 as a reversal of precedence under Article 23.9.2. Although Howden (1968) recognized Gymnodus as a synonym of Osmoderma, he did not explicitly declare the older name as a nomen oblitum. Therefore I here reverse the precendence of Gymnodus and place it as a junior synonym of Osmoderma under Article 23.9.2 of the Code. The requirement is that Osmoderma be used as a valid name in "at least 25 works, published by at least 10 authors in the immediately preceding 50 years and encompassing a span of not less than 10 years." In compliance with the requirements of the Code, the following list of qualified publications, in chronological order, used Osmoderma as a valid generic name, which is sufficient evidence that it is in prevailing usage: Ritcher 1958, Dillon and Dillon 1961, Ritcher 1966, Arnett 1968, Howden 1968, Ritcher 1969a, b, Ratcliffe 1977, Lago et al. 1979, Kusui 1986, Sternbergs 1988, Baraud and Tauzin 1991, Ratcliffe 1991, Ohno 1992, Storey et al. 1993, Sparacio 1994, Tauzin 1994a, Tauzin 1994b, Massa 1995, Downie and Arnett 1996, Tauzin 1996, Prunier 1999, Ranius 2000, Hardtke 2001, Harpootlian 2001, Ranius 2001, Ranius and Hedin 2001, Boucher 2002, De La Puebla et al. 2002, Hedin and Ranius 2002, Ranius 2002, Ratcliffe 2002, Tauzin 2002, Ugarte-San Vicente and Ugarte-Arrue 2002, Larsson et al. 2003.

The porcupinefish (Teleostei: Diodontidae) generic name Gymnodus Delfortrie, 1871 is a junior homonym of Gymnodus Kirby, 1827. Gymnodus Delfortrie is currently considered a junior synonym of Diodon Linnaeus, 1758, therefore no replacement name is needed.

Type Species. Scarabaeus eremita Scopoli, 1763 (now Osmoderma eremita) by monotypy.

\section{Tetrophthalmus Kirby, 1827}

Tetrophthalmi: Kirby 1827 [original spelling].

Tetrophthalmus: justified emendation.

Nomenclatural Status. Available but invalid name, junior synonym of Stegopterus Burmeister and Schaum, 1840. Kirby (1827) described this subgenus for the species Trichius sutularis. The specimen(s) Kirby described was (were) "from Java." I suspect that the specimens were mislabeled because no trichiines from southeastern Asia match the description given. Later, Burmeister and Schaum (1840) indicated that they were renaming this taxon as Stegopterus (a small genus endemic to South Africa). Reasons for their failure to use Kirby's name are unknown. Kirby's original description of Tetrophthalmus is vague but does match specimens of Stegopterus. Stegopterus has not been used enough in the literature to qualify for the reversal of precedence criteria in Article 23.9.1.2, therefore, I have made an application to the Commission of Zoological Nomenclature to conserve Stegopterus by reversal of precedence with Tetrophthalmus. 
Article 82.1 of the Code instructs that the name in prevailing usage (Stegopterus) must be maintained until the case is ruled on by the commission. I here designate Trichius suturalis Gory and Percheron as the type species of Stegopterus since a type species has never been designated for this genus.

The chewing lice (Phthiraptera: Amblycera: Menoponidae) generic name Tetrophthalmus Große, 1885 is a junior homonym of Tetrophthalmus Kirby, 1827. Tetrophthalmus Große is currently considered a junior synonym of Piagetiella Neumann, 1906, therefore no replacement name is needed.

Type Species. Trichius sutularis Kirby, 1827 (now Stegopterus sutularis) by monotypy.

\section{Trichinus Kirby, 1827}

Trichini: Kirby 1827 [original spelling].

Trichinus: Kirby 1837 [justified emendation].

Nomenclatural Status. Available but invalid name, junior synonym of Trichiotinus Casey, 1915. Although Trichiotinus is clearly in prevailing usage, Article 23.9.1 cannot be used for a reversal of precedence with Trichinus because the latter name was used once in the past century as a valid name (by Hatch 1972). Instead, I have made an application to the Commission of Zoological Nomenclature to conserve Trichiotinus by reversal of precedence with Trichinus. While a decision is pending on this case, Article 82.1 of the Code instructs that the name in prevailing usage (Trichiotinus) must be maintained.

Hoffmann (1935) discussed the usage of Trichiotinus and Trichinus. He rejected the usage of Trichini because Kirby " applied a plural ending to this... name." However, Article 18.8.1 clearly states that such names should be considered available and directs taxonomists to emend the name to have the correct stem (in this case Trichinus Kirby, 1827). Hoffmann (1935) also considered Trichina Meigen, 1830 (Diptera: Empididae) to be a homonym of Trichinus Kirby. However, these names are not homonyms under the Code.

Type Species. Trichius piger Fabricius, 1775 (now Trichiotinus piger) by subsequent designation (Kirby 1837).

\section{On the gender of Trigonopeltastes Burmeister and Schaum, 1840 and Apeltastes Howden, 1968}

Confusion and inconsistencies exist in the literature on the gender of Trigonopeltastes and Apeltastes. These names are both derived from the Greek noun peltestês, which means "one who bears a light shield." This word is masculine in gender, therefore Trigonopeltastes and Apeltastes should also be considered masculine in gender (following Article 30.1.1 of the Code). The following is a checklist of species in both genera with the correct endings.

Apeltastes Howden, 1968

Apeltastes chiapasensis Howden, 1994

Apeltastes elongatus Howden, 1968 
Trigonopeltastes Burmeister and Schaum, 1840

Archimedius Kirby, 1827 (junior synonym)

Euclidius Kirby, 1827 (junior synonym)

Roplisa Casey, 1909 (junior synonym)

Trigonopeltastes archimedes Schaum, 1841

Trigonopeltastes barbatus Howden and Joly, 1998

Trigonopeltastes delta (Forster, 1771)

Trigonopeltastes deltoides (Newman, 1838)

Trigonopeltastes discrepans Howden, 1968

Trigonopeltastes femoratus Howden, 1968

Trigonopeltastes floridanus (Casey, 1909)

Trigonopeltastes frontalis Bates, 1889

Trigonopeltastes geometricus Schaum, 1841

Trigonopeltastes glabellus Howden, 1988

Trigonopeltastes intermedius Bates, 1889

Trigonopeltastes kerleyi Ricchiardi, 2003

Trigonopeltastes nigrinus Bates, 1889

Trigonopeltastes carus Bates, 1889 (junior synonym)

Trigonopeltastes pontilis Howden, 1988

Trigonopeltastes sallaei sallaei Bates, 1889

Trigonopeltastes sallaei sinaloensis Howden, 1968

Trigonopeltastes simplex Bates, 1889

Trigonopeltastes thomasi Howden and Ratcliffe, 1990

Trigonopeltastes triangulus (Kirby, 1819)

Trigonopeltastes nigra Burmeister, 1846 (junior synonym)

Trigonopeltastes truncatus Howden, 1968

Trigonopeltastes variabilis Howden, 1968

Trigonopeltastes wappesi Howden, 1988

\section{Acknowledgments}

Thanks to Matt Paulsen and Brett Ratcliffe (both University of Nebraska-Lincoln) for help in finding references, Al Newton (Field Museum of Natural History) for advice on nomenclatural issues, and Thomas Rinkevich (University of Nebraska-Lincoln) for information on Latin grammar. This project was supported by an NSF/BS and I grant (DEB-0342189) to A.B.T. Smith and an NSF/PEET grant (DEB-0118669) to M. L. Jameson and B. C. Ratcliffe.

\section{Literature Cited}

Ádám, L. 1994. A check-list of the Hungarian Scarabaeoidea with the description of ten new taxa (Coleoptera). Folia Entomologica Hungarica 55:5-17.

Arnett, R. H. 1968. The beetles of the United States. American Entomological Institute, Ann Arbor, MI. 1112 pp.

Baraud, J., and P. Tauzin. 1991. Une nouvelle espèce europeenne du genre Osmoderma Serville. (Coleoptera Cetoniidae Trichiinae). Lambillionea 91:159-166.

Boucher, S. 2002. Un nouvel Osmoderma endemique des monts Sikhote-Aline (Coleoptera, Cetoniidae). Bulletin de la Societe Entomologique de France 107:425-427.

Burmeister, H., and H. Schaum. 1840. IV. Kritische Revision der Lamellicornia melitophila. Zeitschrift für die Entomologie 2(2):353-378.

De La Puebla, P. B., J. I. López-Colón, and J. R. Samper. 2002. Presencia en Cantabria de Osmoderma eremita (Scopoli, 1763) y nueva localización de Serica brunnea (Linnaeus, 
1758) (Coleoptera, Scarabaeidae, Cetoniinae y Melolonthinae). Boletín de la SEA 30:183184.

Dechambre, R.-P. 2001. Du bon usage du principe de priorité ou pourquoi Gnorimus doit rester Gnorimus (Coleoptera, Cetoniidae, Trichiinae). L'Entomologiste 57(6):229-232.

Dillon, E. S., and L. S. Dillon. 1961. A manual of common beetles of Eastern North America. Row, Peterson, and Company, Evanston, IL. 884 pp.

Downie, N. M., and R. H. Arnett. 1996. The beetles of Northeastern North America, volume 1. Sandhill Crane Press, Gainesville, FL. 880 pp.

Hardtke, H. J. 2001. Osmoderma eremita Scopoli in Possendorf (Col., Scarabaeidae). Entomologische Nachrichten und Berichte 45:235-236.

Harpootlian, P. J. 2001. Scarab beetles (Coleoptera: Scarabaeidae) of South Carolina. Biota of South Carolina 2:1-157.

Hatch, M. H. 1972. The beetles of the Pacific northwest. Part V: Rhipiceroidea, Sternoxi, Phytophaga, Rhynchophora, and Lamellicornia. University of Washington Publications in Biology 16:1-662. [Dated 1971].

Hedin, J., and T. Ranius. 2002. Using radio telemetry to study dispersal of the beetle Osmoderma eremita, an inhabitant of tree hollows. Computers and Electronics in Agriculture 35:171-180.

Hoffmann, C. H. 1935. The biology and taxonomy of the genus Trichiotinus (ScarabaeidaeColeoptera). Entomologica Americana 15:133-209.

Howden, H. F. 1968. A review of the Trichiinae of North and Central America (Coleoptera: Scarabaeidae). Memoirs of the Entomological Society of Canada 54:1-77.

International Commission on Zoological Nomenclature. 1999. International Code of Zoological Nomenclature. 4th ed. International Commission on Zoological Nomenclature, London. $306 \mathrm{pp}$.

Kirby, W. 1827. A description of some new genera and species of petalocerous Coleoptera. Zoological Journal 3(10):145-158.

Kirby, W. 1837. The insects. In: Fauna Boreali-Americana, part 4 (J. Richardson, W. Swainson, and W. Kirby, editors). Josiah Fletcher, Norwich. 325 pp.

Kusui, Y. 1986. Invasive record of Osmoderma barnabita Motschulsky from an imported log. Entomological Review of Japan 41:77.

Lago, P. K., R. L. Post, and C. Y. Oseto. 1979. The phytophagous Scarabaeidae and Trogidae (Coleoptera) of North Dakota. North Dakota Insects 12:1-131.

Larsson, M. C., J. Hedin, G. P. Svensson, T. Tolasch, and W. Francke. 2003. Characteristic oder of Osmoderma eremita identified as a male-released pheromone. Journal of Chemical Ecology 29:575-587.

Massa, B. 1995. Osmoderma heremitum meridionale Tauzin 1994 sinonimo di Osmoderma cristinae Sparacio 1994 (Insecta Coleoptera Cetoniidae). Naturalista Siciliano 19:307-308.

Ohno, M. 1992. Bibliography of the selected important animals occurring in Japan. (19a) Osmoderma opicum Lewis, 1887 (Coleoptera, Scarabaeidae). (2). Lamellicornia 8:22-33.

Prunier, D. 1999. Quelques observations sur la biologie d'Osmoderma eremita Scop. Coleopteriste 35:23-24.

Ranius, T. 2000. Minimum viable metapopulation size of a beetle, Osmoderma eremita, living in tree hollows. Animal Conservation 3:37-43.

Ranius, T. 2001. Constancy and asynchrony of populations of a beetle, Osmoderma eremita living in tree hollows. Oecologia 126:208-215.

Ranius, T. 2002. Osmoderma eremita as an indicator of species richness of beetles in tree hollows. Biodiversity and Conservation 11:931-941.

Ranius, T., and J. Hedin. 2001. The dispersal rate of a beetle, Osmoderma eremita, living in tree hollows. Oecologia 126:363-370.

Ratcliffe, B. C. 1977. Descriptions of the larva and pupa of Osmoderma subplanata (Casey) and Cremastocheilus wheeleri LeConte (Coleoptera: Scarabaeidae). Journal of the Kansas Entomological Society 50:363-370.

Ratcliffe, B. C. 1991. The scarab beetles of Nebraska. Bulletin of the University of Nebraska State Museum 12:1-333. 
Ratcliffe, B. C. 2002. Scarabaeidae Latreille 1802: Cetoniinae Leach 1815, chapter 34-VI. In: American Beetles, volume 2 (R. H. Arnett, M. C. Thomas, P. E. Skelley, and J. H. Frank, editors). CRC Press, Boca Raton, Florida. 861 pp.

Ritcher, P. O. 1958. Biology of Scarabaeidae. Annual Review of Entomology 3:311-334.

Ritcher, P. O. 1966. White grubs and their allies. Oregon State University Press, Corvallis, OR. 219 pp.

Ritcher, P. O. 1969a. Spiracles of adult Scarabaeoidea (Coleoptera) and their phylogenetic significance. I. The abdominal spiracles. Annals of the Entomological Society of America 62:869-880.

Ritcher, P. O. 1969b. Spiracles of adult Scarabaeoidea (Coleoptera) and their phylogenetic significance. II. Thoracic spiracles and adjacent sclerites. Annals of the Entomological Society of America 62:1388-1398.

Sparacio, I. 1994. Osmoderma cristinae n. sp. di Sicilia (Insecta Coleoptera: Cetoniidae). Naturalista Siciliano 17:305-310.

Stephens, J. F. 1839. A manual of British Coleoptera. Longman, Orme, Brown, Green, and Longmans, London. $443 \mathrm{pp}$.

Sternbergs, M. 1988. Occurrence of the beetle Osmoderma eremita Scop. in Latvia. Latvijas Entomologs 31:39-40.

Storey, K. B., T. A. Churchill, and D. R. Joanisse. 1993. Freeze tolerance in hermit flower beetle (Osmoderma eremicola) larvae. Journal of Insect Physiology 39:737-742.

Tauzin, P. 1994a. Le genre Osmoderma Le Peletier et Audinet-Serville 1828 (Coleopt., Cetoniidae, Trichiinae, Osmodermatini) systématique, biologie et distribution (première partie). L'Entomologiste 50:195-214.

Tauzin, P. 1994b. Le genre Osmoderma Le Peletier et Audinet-Serville 1828 (Coleopt., Cetoniidae, Trichiinae, Osmodermatini) systématique, biologie et distribution (deuxième partie). L'Entomologiste 50:217-242.

Tauzin, P. 1996. Complément à la note sur le genre Osmoderma (Coleopt., Cetoniidae, Trichiinae). L'Entomologiste 52:105-106.

Tauzin, P. 2000. Le genre Aleurostictus Kirby, 1827: Contribution à sa connaissance et precision sur la distribution des espèces (Coleoptera, Cetoniidae, Trichiinae, Trichiini). L'Entomologiste 56:231-281.

Tauzin, P. 2002. Osmoderma eremitum: Complements sur sa distribution en France et nouvelle information sur la taxonomie du genre (Coleoptera, Cetoniidae, Trichiinae, Osmodermatini). L'Entomologiste 58:145-151.

Ugarte-San Vicente, I., and B. Ugarte-Arrue. 2002. Primer registro de Osmoderma eremita (Scopoli, 1763) para la Comunidad Autonoma Vasca y de Aleurostictus variabilis (Linnaeus, 1758) para Alava (Norte de la Peninsula Iberica) (Coleoptera, Cetoniidae). Estudios del Museo de Ciencias Naturales de Alava 17:147-150.

Whitehead, P. F. 2003. The noble chafer Aleurostictus nobilis (L., 1758) (Col., Scarabaeidae) in Britain. Proceedings of the Second Pan-European Conference on Saproxylic Beetles 6:1-15.

(Received 25 September 2003; accepted 25 March 2004. Full page charges borne by the author. Publication date 13 July 2004.) 